\title{
A postcolonial philosophy of religion and interreligious polylogue
}

1 $\mathrm{n}$ this article, an agenda for the development of a philosophy of religion which is informed by the challenges and possibilities of religious plurality is suggested. It is argued that the philosophy of religion as an academic discipline is in need of a kind of reconstruction if it is to maintain its relevance and connection to actual religious phenomena as they present themselves globally. The problem originates in the fact that the modern concept of religions has a distorting effect when applied to non-western traditions.

The article focuses on a way to understand religious diversity by using aspects of Heidegger's fundamental ontology to illuminate different ways of being religious within the same tradition and also to find similar religious dispositions across traditions. It is argued that this can inform interreligious dialogue so that this dialogue-or rather, polylogue-itself can serve as a tool to develop a postcolonial existential philosophy of religion.

Part of this project would be to find and apply concepts and categories by reading religious traditions and subtraditions through each other. The article ends with a few suggestions on how this can be done, in this case by drawing on traditions from India.

\section{Introduction: conceptions of interreligious dialogue}

The questions of what interreligious dialogue is and how it should be conducted are, of course, dependent on the question of why it is carried out and what outcome is desired or expected. All this is dependent upon which context the dialogue is carried out in. Theorizing about interreligious dialogue must therefore also be put into a context. There is no neutral philosophy of religion that can form the basis of such theorizing. When for example Paul Griffiths (1991) and Keith Yandell (1974: 185-6) theorize about the logic of and criteria for interreligious dialogue, that very theorizing itself is an expression of a Christian theology that is characterized by Western pre-Kantian metaphysics. And it is implicitly, or even explicitly, apologetic in nature. It is thus more precisely a Christian theology of religions, where the position of the dialogue partner is preconceived in terms of someone holding truth claims akin to one's own, albeit incomplete or plainly false ones.

Interreligious dialogue in the version described above is religiously motivated, with the aim of developing one's own theology. However, the call for dialogue in the political and social context is generally not theoretically motivated in that sense. The focus is rather to improve the social and political situation by developing tolerance and openness. The need to enhance understanding and cooperate in the attempt to overcome religiously motivated conflicts and develop peaceful coexistence is urgent in societies where religious plurality is a conspicuous fact. To be sure, a certain kind of religiousness, characterized by metaphysical realism, may impinge negatively on the social and political situation, due to the universalistic and philosophically problematic nature of its theoretical stand. Therefore, some theological positions may be very problematic when tolerance and openness are the desired outcomes.

Apart from contexts where religions are seen to cause problems, there is also a potential threat operating in today's world where religious traditions could be helpful in contributing to a positive change. I am referring to the ecological crisis; environmental catastrophes and climate changes caused by extreme exploitation of nature and polluting activities. Since a Western consumerist way of life is now spreading rapidly all over the world, this threat is becoming immanent. I think there is some weight in the words of Philip Goodchild when he says that 
[i]n order to survive the ecological threat, dominant powers will have to undergo unparalleled transformations of social, cultural, political, economic and ecological practice and consciousness. Indeed, for such a conversion to gain sufficient power, religious motives may have to come into play to replace a system based on greed and consumption. (Goodchild 2002: viii.)

Many ways of being religious, independent of tradition, do not sanction the present exploitation of nature (Nasr 1997), and if these religious existential dispositions come to the fore, they may inspire major changes in life styles. In order for this to come about interreligious dialogue may be an important tool for bringing mutual inspiration and influence to bear on the public sphere.

What is obvious here is that we cannot be concerned only with the Western part of the world. It is a global problem and if we are to involve religion, we have to do it globally. For practical and moral reasons, we have to accept that the fact of religion is the fact of religious plurality. I claim that there is a plurality of ways of being human and in understandings of what it means to be a human being. By this I want to say that there is no one religion or worldview that can be shared by all human beings. Indeed, due to the indecisiveness of the question of what it means to be human, there should not be any attempt to politically reinforce any one such understanding. I am well aware that our history shows ample examples of such attempts, and that they are not only historical, but quite conspicuous in today's world. There are religious fundamentalists with such views. There are those with political ideologies. There are representatives of a scientistic position. I do not believe in any such utopian dreams. In fact, I think they are unwanted. I shall argue that they represent a certain existential disposition, characterized by a controlling mood. I claim that what can unite people is not a shared worldview, but a shared acceptance and tolerance of each other's differences.

To understand and conceptualize differences, then, becomes a quest for an existential philosophy of religion, where interreligious dialogue, or polylogue as I would like to call it, becomes a contributing factor. If we want to understand religious phenomena globally, I am of the opinion that certain conceptions of religion must be put into question, or at least stripped of their universal pretensions.

\section{The modern concept of religion}

Many postcolonial thinkers have recently seriously questioned the modern concept of religion, especially when applied to Eastern religious phenomena. I am very much in agreement with this criticism. For the sake of convenience, I will retain the term 'religion' but only in its most general sense, as a human phenomenon, different from other human phenomena such as art and economics. Richard King has the following to say about the modern concept of religion:

The concept of 'religion' is the product of the culturally specific discursive processes of Christian history in the West and has been forged in the crucible of inter-religious conflict and interaction. The term thus implies a pluralistic context. As Balagangadhara points out, Christianity has generally served as the prototypical example of a religion and thus as the fundamental yardstick or paradigm-case for the study of 'other religions'. This being the case, one should acknowledge that the comparative study of religion remains founded upon a conceptual framework that is unmistakably theological and Christian in orientation. (King 2002: 40.)

As Wilfred Cantwell Smith has pointed out, the term 'religion' actually stands for several different concepts (Smith 1963: 48-9), one of which King here refers to, and which I prefer to call the modern concept of religion'. I very much share the postcolonial critique of this concept as presented by thinkers such as Timothy Fitzgerald (2010) and S. N. Balagangadhara (1994). Balagangadhara gives an extensive argument in his book, 'The Heathen in His Blindness': Asia, the West and the Dynamics of Religion, to the effect that India, traditionally, has a culture without 'religion' and without 'worldview' in the Western sense of the terms.

My concern in this paper is to stress the distinction between 'religiousness' and 'religion' and to categorize different kinds of religiousness. Although almost half a century has passed since Wilfred Cantwell Smith in his book The Meaning and End of Religion (1963) convincingly argued for an abandonment of the modern concept of religion, this very concept is still the cause of much confusion, misrepresentation and even oppression. I argue that this is due to the fact that those who adhere to the concept represent only a certain kind of religiousness, which they extrapolate to religious phenomena in general. Smith 
expresses it in this way:

I have become strongly convinced that the vitality of personal faith, on the one hand, and, on the other hand (quite separately), progress in understanding-even at the academic level-the traditions of other people throughout history and throughout the world, are both seriously blocked by our attempt to conceptualize what is involved in each case in terms of (a) religion (Smith 1963: 50).

Smith argues for retaining the concept of religion when referring to the faith of the religious subject, but for abandoning the concept of 'religion' as an overt system of beliefs, practices, values etc., idealized in theologies and studied as an empirical phenomenon historically and sociologically. Although the modern concept of religion was developed within a specific Christian historical situation, where the necessity to employ putatively universal conceptions of truth and reason made its appearance, it was used in the construction of so-called world religions into more or less conflicting belief systems with, as one imagined, universal pretensions. For Smith 'faith' was the universal and primordial concept and I claim, as does Kuk-Won Bae, that his arguments rest on the philosophical anthropology of a homo fidei (Bae 2003). I see religiousness in much less essentialist and universal terms than Smith, and consequently the conceptualization of religiousness in my version becomes a creative, complex and provisional matter.

\section{The colonial misrepresentation of non-Western religion}

In this section I will bring to light distorted understandings of religious phenomena globally, caused by the colonial and imperial endeavours of the West during recent centuries. This misunderstanding and misrepresentation, I claim, is caused by a combination of an obvious aspiration for domination, both religious and economic, as well as of more innocent prejudices. These more innocent prejudices have been the underlying foundation when theorizing about religion within academic disciplines such as anthropology, religious studies, and the philosophy of religion.

Along with the Enlightenment and the modern project, a certain existential disposition, characterized by exploitation, knowledge and control, came to dominate Western culture. Philosophical anthropol- ogy that saw the human being primarily as a needfulfilling agent became the tacit point of departure when studying human behaviour globally. There was an idea that all human behaviour could be explained from this perspective, in roughly the same way as the workings of nature could be explained by referring to basic natural laws. This came to inform the first attempts to build theories of religion. Thus, for example, James George Frazer assumed that the activities of local (what he called primitive) people were centred around the struggle to survive. Religion, in his view, thus became a naïve way of controlling and transforming nature to suit human needs.

Theorizing about religion from a presumed neutral perspective in the West started earlier in history with philosophers such as Hobbes, Locke, Hume and Kant and was part of the Enlightenment project. These philosophical perspectives on religion were, I claim, brought about by social, moral and political problems occurring from within the Christian context, where religion was used by political and religious leaders to enhance their power through victimization and war. Out of this specifically Christian context developed the modern concept of religion as an overt system of beliefs, practices, values etc., which became the conceptual framework for studying the so-called other religions, with the invention of the concept of 'world religions' as a consequence. This concept brings about a specific understanding of religious phenomena that has had immense influence and has come to support the colonial and imperial interests of the West.

After the so-called 'death of God', the presumed universal narrative of Christianity has been supplemented and transgressed by the narrative of modernity, where the superior position of the West is established through evolutionary thought and historicism. Even non-religious theorists did, however, consider Christianity as the most advanced religion, but that it was now, due to the progress of man, being replaced by a scientific worldview. To explain human behaviour by referring to an overall explanation of what there is, and in terms of certain beliefs in origin and causality, overall in expressions of an attempt of bringing order to chaos, is, however, an expression of a certain existential disposition, a certain very specific and provincial way of being religious, which has unfortunately been considered universal and which is reflected in the scientism of today. Richard Dawkins would in this sense represent the non-religious mirror-image of this kind of religiousness (Dawkins 2006). So my argument is that what the modern con- 
cept of religion is representing is a certain kind of religiousness, based on what Martin Heidegger terms onto-theological presumptions (Heidegger 1953).

Since the time of Heidegger it has been common to distinguish between two different kinds of inquiry. One is the ontic, which deals with different kinds of beings or entities in their totality of causal connectedness. The other is the ontological, which investigates the being of these entities, for example what it means to be a human being, the manner or way it shows itself or comes to presence. Now, if religious phenomena are studied under the modern concept of religion in relation to systems of belief, as an ontic inquiry, then certain consequences follow. The consequences will be different if religious phenomena are studied as an ontological inquiry. (Schrag 1999: 69-70.) The religiousness involved in the ontic inquiry is primarily interested in 'what there is.' It is important for the religious person to have the right beliefs about the order of things. It is governed by a controlling mood. When religious behaviour is studied from an historical or sociological point of view, the first question asked is thus: 'What do they believe?' This way of investigating religious behaviour in general tends to be distorting, since it is primarily concerned with belief in 'what there is'. To illustrate what I mean, I will quote Frederick Streng, who has observed that anyone talking about the nature of reality does not stand outside of that to which they refer, but stands within it (Streng 1995: 205). After comparing three different structures of ultimate transformation-one Christian (represented by Paul Tillich), one Daoist (represented by Hellmut Wilhelm) and one Buddhist (represented by Keiji Nishitani)—Streng concludes:

In the first case [Tillich] we saw that the sense of reality assumed the expectation of essences whereby life is given value. Life has a reason and meaning through the categorization of what "is". The sense of reality in the second case [Wilhelm] focused on a holistic grasp of principles which themselves were not abstractions of essences but intuitions of moving forces within a concrete situation where a person lived. In the final expression [Nishitani], regarding the field of emptiness, the sense of reality is much more a state of consciousness or an attitude whose chief quality is found in the paradoxical expression that one knows "selfhood" when one is aware of the noself. These formulations of ultimate reality, then, are not seen as "mere speculation" or systems of verbal abstraction. Rather, the formulations themselves become ontological activities whereby a person's sense of value and reality are given form and content.

We may conclude, therefore, that the nature of reality is manifested as much in the process of knowing and valuing it as in the formulations that specify it. In this sense, a cross-cultural philosophy of religion will be well served by looking beyond the labels of systems of ideas to the existential importance that they have in disclosing the truth about life. (Streng 1995: 222-3.)

This example shows that, of the three, it is only one, Tillich, who for the meaning and reason of his religious endeavour is dependent on a categorization of what there 'is'. Thus I suggest, that for a better understanding of religiosity in general, globally, we would benefit by changing our focus to the existential disposition of the religious subject.

\section{What is authentic religion?}

If we recognize that the modern concept of religion (as a system of beliefs about what there is) itself is the problem, then such putative perplexities as multireligious belonging would no longer be a perplexity. We would realize that a single Chinese person's being simultaneously a Confucian, a Buddhist and a Daoist is not an example of a religious dichotomy. It is rather indicative of something wrong with the modern concept of 'religion' as applied to Confucian, Buddhist and Dao religiosity.

Using the modern concept of religion when interpreting contemporary religious phenomena in the West may also be misleading. So-called multiple religious belongings in the West are detected by, for example Peter Phan, (2003) and Catherine Cornille (2002). Can it be ascertained from a non-confessional point of view whether persons who involve various different religious narratives and symbols in their religious practice are really Christians or Buddhists, for example? Is it not much more interesting, and fruitful in the dialogic encounter, to investigate and mutually conceptualize what kind of religiousness is involved? I have a colleague who is doing research on a Sufi group in the US. When asked whether they are Muslims, they are hesitant to answer 'yes' so they give the answer: 'We are not not Muslims.'

One interesting question in this connection is: what is religious authenticity? Generally the so called 
mixing of religions is considered inauthentic. But if we rid ourselves of the concept of religion, where do we stand then? The interesting thing is to see what function religious symbols and narratives have in the life of the religious subject? What are her expectations and motives, what kind of religiousness is she expressing?

\section{Religious diversity: problems and possibilities}

I will bring up another misconception arising from the modern concept of religion, which has had unfortunate consequences when it comes to understanding interreligious dialogue, what it entails and what can come out of it. So, first of all: 'What is religious diversity?' The question is important because many philosophers of religion have in recent decades discussed so-called problems of religious diversity, where a preconception of what this diversity is all about is taken for granted. This preconception also takes for granted that religious diversity entails problems. This, of course, raises another question: why problems and what kind of problems? To some, the answer is obvious. The media are continually reporting on so-called religious conflicts with violent political and social consequences. When religion is debated in the public sphere, it is most often these kinds of problems that are the concern. However, this only mirrors a very limited form of religiousness, which unfortunately then is given a lot of public space, overshadowing other forms. Unfortunately, academic fields like the philosophy of religion, philosophical theology and to some extent even religious studies are often preoccupied with a concept of religion that supports this situation.

Now, a phenomenon related to religious diversity is interreligious dialogue, and this is often seen as a way to combat social and political conflicts. Theoretical reflections on the nature, possibilities and desirability of interreligious dialogue have, along with problems of religious diversity become the subject of a subset of the academic philosophy of religion. Related to this is also the so-called theology of religions, which is a kind of philosophical theology where from within the Christian tradition you reflect over how to deal with the fact of religious diversity. The preconception involved in these attempts is the presupposition that the problems of religious diversity primarily entail problems of conflicting truth claims about a so-called Ultimate Reality. The point of departure is onto-theology. Although this kind of philosophizing is conceived of as being able to encompass all the major religious traditions, the so-called world religions, it in fact only expresses a very specific kind of religiousness, extrapolated to religious phenomena in general. Thus it is clinging on to a concept of religion that is outdated and does not conform to religious phenomena as they manifest themselves today. The whole enterprise becomes a concern only for certain Christian academic scholars. I have a vision for a much more creative form of interreligious dialogue, where a non-tradition-specific space for conceptualizing and categorizing is developed.

A prerequisite for creating a non-tradition-specific space is a willingness to dislocate oneself. A postcolonial situation offers an opportunity to place oneself on an equal standing with the other. It implies a rupture, where one's own tradition and narrative is parenthesized. If one adheres to Hans-Georg Gadamer's idea of dialogue and philosophical hermeneutics, one may consider this impossible. But it is impossible only if one sees the dialogic encounter as a way of using the other as a means to self-improvement rather than as taking an existential risk. I view a postcolonial philosophy of religion as a creative activity involving interreligious polylogue. The purpose is to develop concepts and categories concerning motives, goals and various ideas of the good.

\section{Fundamental ontology: attunement and understanding}

If we apply Heidegger's ideas, developed in what he calls fundamental ontology, that we are attuned to the world in different ways that determine how we understand our life worlds and act in them (Heidegger 1996: 123-44), then we will understand that it is not one worldview that determines our actions, but our existential disposition and the moods that we are tuned into that determine how we experience and conceptualize our various life worlds.

When it comes to moods, there are those who like to stress the role of social conditioning. Hubert Dreyfus, for one, suggests that mood should refer to 'cultural sensibility' and be located in the public sphere of the culture to which one belongs, not in the individual (Dreyfus 1991: 169-70). I admit that cultures and communities may be dominated by certain moods, but it is important to stress that individuals who find themselves governed by other moods can reject these.

Another point I would like to make is that basic moods in general are universally human. Moods like love, grief and fear are found in all human cul- 
tures. Having said this, I shall suggest how one could conceive of religious diversity by giving attention to some basic human moods. To discern differences by giving attention to moods is, I think, a field that is almost unexplored. What I am here suggesting is just one, probably of many, ways to start. By observing religious traditions and religious phenomena, I have detected three basic human dispositional moods, expressing themselves in various ways in religious contexts. These I have termed:

The mood of exploitation.

The mood of renunciation.

The mood of dedication.

The mood of exploitation may not sound very religious. It is probably the most basic human mood, since it is absolutely necessary for maintaining our existence. We need to exploit the world in order to live. However, it becomes religious, for example, when God is seen as sanctioning, or even ordering our exploitation. Rationality is an important aspect of this mood, which may even come to govern the moral and the religious aspects of life. As an example of the exploitative mood, one could cite John Locke, who in his An Essay Concerning Human Understanding (2008) proclaims that the native inhabitants of the American continent are morally inferior to the white man since they lack the ability to exploit their very rich continent, and that it therefore is the moral duty of the white man to carry out this exploitation.

The mood of renunciation is more conspicuously religious. It expresses itself in attempts to renounce the world and become monks, mendicants, eremites or ascetics. It is linked to a view according to which we are entangled in the world by our desires, and that this makes us suffer.

The mood of dedication becomes manifest in the loving service of God in churches and temple and in the service of fellow human beings of limited means. It also comes to expression in religious festivals and pilgrimages.

These are just examples of three basic moods which I claim come to expression in all religious traditions, but express very different kinds of religiousness, which make way for variety within each tradition. They also make it possible to detect similarities in religiousness between traditions in that, for example, a renunciate in one tradition should be able to understand and share experiences with a renunciate of another tradition. (Pfändtner 2010: 89-91.)

\section{Intrareligious differences}

Religious narratives are seemingly open to a variety of interpretations according to moods. I would like, in this connection, to refer to what can be termed 'intrareligious incoherence. Keith Ward has detected within five major religious traditions the existence of a 'double-aspect doctrine' in the context of conceptualizing God or the Ultimate. This doctrine reveals the paradoxical co-existence of both personal and impersonal conceptions of the Ultimate. (Ward 1987: 1568.) Since these conceptions seem to contradict each other, it is unlikely that they originate from a neutral, disinterested space of a universal rationality. More likely then is the assumption that they spring from human experience from within different moods, and since the doctrine is found in several different traditions, it seems as if these moods are trans-cultural. When the same person cultivates both of these conceptions of the Ultimate from within a religious tradition, I suggest that it is a kind of aspect-experiencing, analogous to the aspect-seeing exemplified by the duck-rabbit-picture. However, the concepts are, in the religious context, not developed from sense experience, or the experience of something objectively present, but rather from religious moods, one relational (the mood of dedication) and one unitary (which is linked to the mood of renunciation). Both of these can apparently affect the same individual.

Seeing moods as existential has bearings on how one views a presumed knowledge of God. From my perspective even the so-called natural or philosophical way of attaining a supposed knowledge of God originates in a certain mood, a certain existential disposition. Bernhard Lonergan distinguishes between the intellectual and the experiential paths to a knowledge of God (Jonsson 2002: 33). He presents the intellectual as an unprejudiced possibility, in principle open to everyone, independent of culture. However, I claim that it is actually dependent on the mood of dedication, which expresses itself intellectually as a kind of glorification of God by the intellect. Even this kind of religious taste for 'intellectual devotion' I claim to be trans-cultural. It can be found in all traditions and can therefore function as a means for understanding through dialogue.

That religious moods seem to be transcultural and that religious traditions are pliable and can accommodate quite a variety of moods, I take to be empirically detectable. There is an interchange between the religious narrative and the religious person's mood and her way of valuing her experiences. Thus we have 
seen within all of the major religious traditions, in the course of history, radical reinterpretations of notions within these narratives by individuals in a specific mood and with specific experiences. This has often been considered as heresy, but later on these, we could term them 'new insights', have developed into sub-traditions.

I will give a few examples: we find in the originally non-monotheistic Japanese Buddhist tradition the heretic monk Honen expressing the mood of complete surrender and dependence on the grace of Amida Buddha. Similar moods are prominent in the Hindu bhakti-tradition, where a personal God subsequently gains superiority over the impersonal Brahman. These moods are characterized by devotional love and saving grace resembling ways of being religious in the dominant Christian contexts. However, in the Christian tradition we also find mystics like Meister Eckhart, suspected of heresy within his own tradition, who expresses a religious mood and understanding which, according to many, resemble the ones found in Zen Buddhism (Suzuki 1975).

One important point I would like to stress is that the religious experience of truth is not just a triggering of the intellectual taste, the curious and sometimes mastering desire to conceptualize the Ultimate. It is rather a total life experience, a transformative experience, which includes both aesthetic and ethical elements, and this I take to be true with all traditions. So the moods involved are of a great variety, a fact that has generally not been observed by leading intellectual interpreters (mainly male) of the different traditions. The existential perspective, the turn to the religiousness and experiences of the individual, which nevertheless is not an arbitrary one, will also be a way of disclosing a greater variety of moods through dialogic interaction across traditions. ${ }^{1}$

\section{Drawing from non-Western traditions}

I will now present some ideas of how the conceptualization of religiousness could be carried out by drawing mainly from the Indian tradition. In this way I am not claiming that the Indian tradition is superior in this regard. It is just to give an example of what I am aiming at. By interreligious polylogue, I simply

These observations are often made by feminist philosophers of religion. They claim that if women's religious experiences are considered, a new dynamics of interreligious dialogue will follow. See for example O’Neil 1990, 1993 and Young 1995. mean the attempt, from a number of different traditions, to find concepts and categories that could be understood and applied within a common shared space of religious experiences, motives and expectations. Concepts and categories that can be developed in this way may be seen as akin to Weber's ideal types. They are ideal constructs, meant to help us in understanding one another and a plurality of ways of being human.

First I would like to make clear some of my presuppositions. I claim that the division between the philosophy of religion and the history of religions can no longer be as clear-cut as it once was. I also claim that the atheistic presuppositions of modern secular thinking should be disputed, and as phenomena from within the Christian tradition today are used for critical thinking about religiosity per se, phenomena from, for example, the Indian tradition can be used, and applied to religiosity per se. I claim that this is fruitful and maybe necessary if we are to develop a postcolonial philosophy of religion.

I will now give an example of how concepts from Indian religious traditions can be used to conceptualize different kinds of religiousness. In verse 16 of the seventh chapter of the Bhagavad-gita four kinds of pious people, sukritinah, are said to engage themselves in religious activity: (1) the one who suffers, (2) the inquisitive, (3) the one who desires material gain, and (4) the wise. We find here, thus, certain existential situations that can trigger a religious life, on one condition, of course, that the subject is a sukritinah. Since the motives here are very different, I would like to suggest that the religiousness involved is also of various kinds, or moods. I would also suggest that these differences in religious motives are not confined to the Indian traditions, but can also be found elsewhere and are also not limited to certain times in history.

Another example of categories of religiousness is the Indian division of religiousness into karma, jnana and bhakti-activity, intellectuality and devotion-where the path of karma is characterized by surrendering the fruits of your work, bhakti by devotional love and jnana by philosophical introspection. I claim that also these are categories that can be applied trans-culturally and help us recognize what kind of religiousness is involved.

If we think in these terms, it would in my opinion be much more fruitful to do research on recent religious phenomena such as New Age. We would be able to categorize all kinds of religiousness that now quite hazardously are clumped under the concept of 
New Age. We would also be able to specify phenomena that now go under the very general concept of spirituality.

An aspect of religiousness which I consider to be neglected is the aesthetic. Here we can also draw from the Indian tradition and the concept of rasa, which could be translated as taste. Here the prime motive for religious engagement is to enter into a mood of loving relation to the Supreme with a certain kind of taste, be it as a lover, a parent, friend, or servant. The concept is used in conceptualizing Indian poetry and has been extended to the religious realm. I would say that a lot of religious behaviour and fervour is motivated by aesthetic moods. With this in mind, I think a whole field of creative conceptualizing activity to make more vivid the religious life worlds could take place, akin to the kind we find in the realms of art, literature and music.

If religious scholars would only focus on these aspects of religion we may just experience a re-enchantment after the disenchantment observed by Weber as having been caused by the exploitative mood of greed and consumption in the capitalist modern world.

Willy Pfändtner (Dr.Theol. in Philosophy of Religion, Uppsala University) is Senior Lecturer, Study of Religions, Södertörn University, Sweden. His research interest is postcolonial philosophy of religion. His main publications include Understanding Religious Diversity: A Contribution to Interreligious Dialogue from the Viewpoint of Existential Philosophy (Uppsala 2005), 'Conceiving Religious Diversity' in: Willy Pfändtner \& David Thurfjell (eds) Postcolonial Challenges to the Study of Religion (Uppsala 2008), 'Constructive Dialogical Pluralism: A Context of Interreligious Relations' (Sophia 49, 2010). E-mail address: willy. pfandtner@sh.se.

\section{Bibliography}

Bae, Kuk-Won, 2003. Homo Fidei: A Critical Understanding of Faith in the Writings of Wilfred Cantwell Smith and Its Implications for the Study of Religion. New York: Peter Lang.

Balagangadhara, S. N., 1994. 'The Heathen in His Blindness': Asia, the West and the Dynamic of Religion. Leiden: E.J. Brill.

Cornille, Catherine, (ed.) 2002. Many Mansions? Multiple Religious Belonging and Christian Identity. Maryknoll, NY: Orbis Books.

Dawkins, Richard, 2006. The God Delusion. London: Transworld Publishers.

Fitzgerald, Timothy, 2010. Who Invented Hinduism? Rethinking Religion in India. In: Esther Bloch et al. (eds), Rethinking Religion in India: The Colonial Construction of Hinduism. 114-34. New York: Routledge.
Dreyfus, Hubert L., 1991. Being-in-the-World: A Commentary on Heidegger's Being and Time, Division I. Cambridge, MA: The MIT Press.

Goodchild, Philip, 2002. Capitalism and Religion: The Price of Piety. London: Routledge.

Griffiths, Paul J., 1991. An Apology for Apologetics: A Study in the Logic of Interreligious Dialogue. Maryknoll, NY: Orbis Books.

Heidegger, Martin, 1953. Sein und Zeit. Tübingen: Max Niermeyer Verlag.

-1996. Being and Time. A Translation of Sein und Zeit. Trans. Johan Stambaugh. Albany: State University of New York Press.

Jonsson, Ulf, 2002. Bernhard Lonergans filosofiska teologi. Svensk Teologisk Kvartalstidskrift 78: 30-8.

King, Richard, 2002. Orientalism and Religion: Postcolonial Theory, India and 'The Mystic East'. London \& New York: Routledge.

Locke, John, 2008. An Essay Concerning Human Understanding. Oxford: Oxford University Press.

Nasr, Hossein Seyyed, 1997. Man and Nature: The Spiritual Crises of Modern Man. Chicago: Kazi Publications.

O'Neil, Maura, 1990. Women Speaking, Women Listening: Women in Interreligious Dialogue. Maryknoll, NY: Orbis Books.

-1993. A Model of the Relationship between Religions Based on Feminist Theory. In: Ö J. Kellenberg (ed.). Inter-Religious Models and Criteria. 37-57. New York: St. Martin's Press.

Pfändtner, Willy, 2010. Constructive Dialogical Pluralism: A Context of Interreligious Relations. Sophia 49: 65-94.

Phan, Peter C., 2003. Multiple Religious Belonging: Opportunities and Challenges for Theology and Church. Theological Studies 64: 495-516.

Schrag, Calvin O., 1999. The Problem of Being and the Question about God. International Journal for Philosophy of Religion 45: 67-81.

Smith, Wilfred Cantwell, 1963. The Meaning and End of Religion: A New Approach to the Religious Traditions of Mankind. New York: Macmillan.

Streng, Frederick J., 1995. Structures of Ultimate Transformation and the Hermeneutics of Cross-Cultural Philosophy of Religion. In: Thomas Dean (ed.), Religious Pluralism and Truth: Essays on Cross-Cultural Philosophy of Religion. 205-23. Albany: State University of New York Press.

Suzuki, Dasetz, 1975. Mysticism, Christian and Buddhist. Westport: Greenwood Press.

Ward, Keith, 1987. Images of Eternity: Concepts of God in Five Religious Traditions. London: Darton, Longman $\&$ Todd.

Yandell, Keith, 1974. Religious Experience and Rational Appraisal. Religious Studies 8: 173-87.

Young, Dickey, 1995. Christ in a Post-Christian World: How Can We Believe in Jesus Christ When Those around Us Believe Differently or Not at All? Minneapolis: Fortress. 